\title{
Language acquisition and educational inclusion
}

\section{Educational strategies among multiple disabled blinds}

DOI: $10.46932 / \mathrm{sfjdv} 2 \mathrm{n} 2-026$

Received in: january 1st, 2020

Accepted in: March 30th, 2020

\section{Cláudia Monserrat Rosa de Oliveira Fontoura}

Graduação em Pedagogia e Enfermagem - Universidade Federal do Rio de Janeiro Instituição Atual: Universidade Federal do Rio de Janeiro.

Endereço: Rua Berna, 148 Bairro: Jardim Carioca (Ilha do Governador) Rio de Janeiro - RJ - Brasil E-mail: kcaumonserrat@gmail.com

\section{Maria do Socorro Fortes de Oliveira}

Doutorado em Educação - Universidade Federal do Rio de Janeiro Instituição Atual: Universidade Federal do Rio de Janeiro e Instituto Benjamin Constant Endereço: Rua Licínio Cardoso, 81 Bairro: São Francisco Xavier Rio de Janeiro - RJ - Brasil

E-Mail: aprendizfortes@gmail.com

\section{Maria Vitoria Campos Mamede Maia}

Doutorado em Psicologia Clínica - Pontifícia Universidade Católica do Rio de Janeiro Instituição Atual: Universidade Federal do Rio de Janeiro

Endereço: Av Jardins de Santa Monica 100 Bloco 5 apto 802 Bairro: Barra da Tijuca Rio de Janeiro RJ - Brasil

E-mail: mariavitoriamaia@gmail.com

\begin{abstract}
This research deals with the language acquisition and the educational inclusion of multiple disabled blind people. The aim was to analyze how three instruments, created so that early childhood educators of the Benjamin Constant Institute could help oral communication and inclusion of blind students with multiple disabilities. The qualitative research, of the ethnographic type, had as subjects two adolescents. The analysis of the results used the bardinian method and pointed out the development of language and interaction between the pairs, allowing the inclusion in a regular classroom.
\end{abstract}

Keywords: games and games, language acquisition, multiple handicapped blinds, educational inclusion

\section{INTRODUCTION}

This article is about the practice to facilitate the socialization and oral communication of blind with multiple disabilities students. The report of this research is part of a more extensive research, "Creativity and Education: different languages habituating the educational space" (MAIA, 2016), in which it is studied the importance of the teaching-learning process. Games and plays were used on the daily routine of blind with multiple disabilities students of Benjamin Constant Institute (IBC), being the games and plays a pedagogical resource whose usage is desired to be extended beyond the school, 
corroborating autonomy of the referred students. It is believed that sharing and propagation of these games and plays will be useful for the students' families, caregivers, and teachers.

The pedagogical practice developed with the students with multiple disabilities at Benjamin Constant Institute, until the year of 2016, was based on the Functional Ecological Method. Its objective was to provide opportunities for the full development of the students, making it easier their autonomy, inclusion, and participation in their social group, which includes their families, school, and community where they live (JESUS, 2017). One of the main goals was the development of abilities that were relevant to the students' daily life. Since the beginning of 2017, the Benjamin Constant Institute, where the research was done, is restructuring its educational environment, enlarging it to be able to work with the growing number of registrations of blind students with multiple disabilities.

The impairment of the vision and oral communication may represent a determinant factor in the desocialization of disable people, making it necessary a transformative action to minimize this disorder. Nunes (2003) informs that the communication done via language represent the most important process in human development. Assumpção \& Valle (2008) agree with this approach when they say that the language is the instrument of communication, and it contributes to the organization of the thoughts, making it easier to transmit ideas, information, and communication of the feelings.

Based on these reflections, this study was born: May the utilization of pedagogical practices as games and plays be used to improve the socialization and oral communication of blind with multiple disabilities students? The objective of this article was to evaluate how three different instruments, created for the teachers of the first years of Education at the Benjamin Constant Institute, could facilitate the development of the oral communication and inclusion of blind with multiple disabilities students.

In order to substantiate this study, other authors were used as base, Glat \& Pletsch (2013), that emphasizes the importance of an Individual Educational Plan to meet the specific needs of each student; Kirk \& Gallagher (2002), which inspires specific adaptations for the multiple disable as an inclusive treatment proposal. Equally, Nunes (2003), develops innovative researches addressing communicative investigations of young people with special needs, the importance of using appropriate resources to meet difficulties in the oral communication, and other possibilities; Siaulys (2010), which reported experiences were examples to enrich the educational practice with the objective to teach and the learning process.

At the current educational scenario, the educator needs to use different strategies to facilitate the learning process of their students, contemplating and respecting the different ways of learning of each student, mainly of those with multiple disabilities (GLAT \& PLETSCH, 2013). With so many differences in the teaching-learning processes of these students, this article presents the utilization of games and plays 
as potential resources to promote the socialization and oral communication, with material that requires individual adaptations to be used to the students' advantage.

\section{BLINDNESS}

It is important to understand about blindness to fully develop a proposal to work with the blind students with multiple disabilities. A disability, which major characteristic is to deprive the visual identification and delimitation of the objects present in the world of people with sight, making social interaction more challenging. Martín \& Bueno (2003), state that a person is considered blind when there is total absence of vision or simply luminous perception making usage of remaining senses, and is user of the Braille systems. Same authors state that the learning of a blind child is similar to the child with sight, in which the individual learns experimenting, seeing, and feeling. However, due to the loss of sight, the child can't perceive the details. Therefore, there is the need for tactile experiences in order to make the learning concrete.

\section{MULTIPLE DISABLE}

The Multiple Disability is an expression used to designate those that present two or more primary disabilities (mental, visual, auditory, physical) associated, affecting, more or less intense, the individual behavior, including his/her social relationships, with compromises that lead to late global development e adaptative capacity (PLETSCH, 2015; BOATO, 2009; CARVALHO, 2000). Kirk \& Gallagher (2002) add that multiple disables are those who have a disability that is considered moderate or serious, needing differentiated and special attention in order to minimize or overcome their limitations.

Working with such groups of disabilities is a challenge for any professional, since the proposals of a pedagogical intervention need to be adapted to the singularities of each individual. In this context, it is important to offer functional activities and significant experiences by different experiences and ways of communication, that are adequate to each characteristic that needs to be emphasized on each student; making possible to obtain more favorable pedagogical results.

This way, it is important that the Alternative Communication is used by the watchful mediators that are interested in communicating with the students in a non-oral way (PELOSI, in NUNES, SUPLINO, WALTER, 2013).

\section{ALTERNATIVE COMMUNICATION}

In the Alternative Communication a variety of resources is used, and they can be manufactured with low cost and technology materials (PLETSCH, 2015). It is common to use hand gestures, facial 
expressional and body language, symbols, bidimensional and tridimensional images, digitalized speech, or even other resources that facilitate the communication between those who cannot communicate vial oral language (NUNES, 2003). It is highlighted that the language is considered a privileged way to acquire symbolical systems and develop the abilities of the interpersonal relationships. That way, when the child finds her/himself impaired to stablish communication through the language, many aspects of his/her development are affected (NUNES, 2003).

This way, choosing games and plays seems to be a favorable option to encourage the communication and socialization of these students.

\section{GAMES AND PLAYS}

In this article, it's advocated that it is important to utilize games and plays in the process to stablish communication with the students.

The games generate possibilities and contribute to exercise cognitive functions and affection of the students (MAIA, 2014). Activities may be included in the daily routine of each individual aiming to encourage development of interpersonal relationships, mainly when done in groups (VISCA, 2009).

The games make possible various opportunities to work with boundaries, creativity, sharing, and intermediation. With them, the students have the opportunity to learn and challenge themselves, living moments of gain and loss (MAIA, 2014). Additionally, the games and plays used as teaching instruments motivate, in a ludic way, the blind students to learn to nominate, locate and dislocate, represent daily situations, create shortcuts, pay attention to details, and memorize. Every time they play, they can acquire a peculiarity of social and communication interactions.

The games and plays are a type of language and the first form of a culture. The same culture that belongs to everyone, therefore, enables everyone to participate with common ideas and objectives (MEYER, 2011). The plays shall occupy a featured place within the school environment. It is highlighted that, for the disability, the play is a fun activity, therefore it's an excellent way to facilitate the action within the objects and environment, enabling and experiencing needed moments to the communication and socialization developments of the blind with multiple disabilities student (SIAULYS, 2010).

Therefore, it is necessary that the students are involved in a secure environment, enabled mainly by the teacher inside the teaching classroom, in order to make the student feel safe to have confidence in $\mathrm{him} /$ herself and on the others around him/her. Its needed to highlight the importance of playing and, at the same time, reassure the possibility of learning while playing, and that by playing we learn how to live. Winnicott (1975, p. 147) says that “(...) playing leads to a natural cultural experience, and actually, constitute its foundation". So, it is viable to consider that the environment is full of possibilities that 
contribute to learning, and through playing, the student can put on different roles, leading to the acknowledgement of rules that are important for the educational inclusion of the blind students with multiple disabilities (MEYER, 2011).

\section{THE RESEARCH}

The methodology used in the research was qualitative with ethnographic focus (GLAT \& PLETSCH, (2011), ANDRÉ (2012), MALHEIROS (2011).

The work done with two young students with age of thirteen and sixteen, enrolled in the first year of elementary school and in the Alternative Learning Program of Benjamin Constant Institute. These students had individual educational program, with activities that would benefit them in the communication, and activities specific for blind disables, as well as other necessary abilities to their socialization and learning. The students had a discrepancy in their global development, needing special attention to their diversity, psychological progress, dynamic participation in their environment, and, specially, in the sociocultural development (BRONFENBRENNER, 2002).

The research in this article was done in 2016, with sessions of fifty minutes of duration twice a week. During this time, after identifying each student singularity and priorities to be contemplated, a game or a play was offered to the student. The rules of the game or play were detailed explained.

The main functions of the games were pedagogical, educational and learning, and the students were observed while playing as well as after, when they were executing their assignments at the environment they lived (home, school, etc.) in order to obtain information that a specific concept or behavior was acquired or developed.

The games and plays were adapted to the characteristics of the students, taking into consideration individual needs, such as, usage of mockups to develop their Communication and Socialization. The students were encouraged to travel through the mockups to develop fine motor coordination, and after they would execute their own real way at school to experience the school routine, routes to the classroom, bathroom, dining area, library, etc. to learn about space-time orientation that they would normally do each day.

The same students were encouraged to report the routes travelled, and this experience contributed to enable them to organize their thoughts, stimulate communication and interpersonal relations with other students. Especially when they were exploring new routes and places, they were encouraged to question, discover a fact or a space, and even raise hypothesis about different ways and alternatives routes to use in their daily life, as an example, in a rainy day, which route should they use? These activities were reported in detail, with objectives of each of them achieved or not. 
The results were registered, as positive or negative, in a spreadsheet with simple items to facilitate identification of the game, is the level of difficulties was appropriate to each student, and the final evaluation of the results.

Lastly, a binder was elaborated with all the pedagogical games and plays in the research field, being a summary of the work done with each student that participated in this research. This binder consisted of functional content, and it was made with low cost materials, and was used as instrument to support and stimulate the students in conversations and interactions with others. In it, the name of the games could be found, as well as their rules, materials used in the confection and main objectives to be achieved. The plays were adapted or created, in such way, as well as the games, to include the name, description on how to play, material used, as well as suggestions on how to illustrate it in a tridimensional way or with concrete objects, or by doing the audio description to facilitate the students imagination and understanding.

Two game and play were chosen to be used with students A and B. During confection of the game number one, denominate "Grandma's cake" (free translation), there was a board, miniatures glued in identified cards, and pieces displayed in a box to be identified and picked up. In the game, each student should grab the piece that corresponded to the proposal of grandma's cake, following the teacher instructions that were created based on a scenario. The teach would say "in order to bake the cake, we need: wood spoon, spatula, etc." The winner was the one who was able to correctly say the name of each instrument/miniature. In this game, the teacher can work with speed, communication, interaction, attention, math, and spatial orientation of each student.

The game number two, named "Full balloons" (free translation), was made from small party balloons, that were filled and colorful. The objective was to make each student to hold as many balloons as possible in the right hand. The teacher would give a sign and the students should run to their friends (that were wearing a rattle) holding the full balloons. When finding their friends, they had to burst the balloons in the right hand and say: this is my balloon. The teacher would stop the play with a sound signal and count the remaining balloons. The winner is the one with more balloons in the right hand.

The play chosen for these two students was made with two characters, created by the students themselves, reminding of their brothers; characters names were Daniel and Karina. A doll was used, with similar features as seven years old child, one-meter high, articulated head and members, with masculine or feminine aspect. Depending on the play, the students were encouraged to talk about gender, corporal schema, perception, collective organization to the development of the play, being individual or in groups. The students were encouraged to talk about their own body, and later to guide themselves and move in an 
organized way around other friends in the classroom or in the scholar environment, reporting what was more significant for each of them.

\section{EVALUATION OF THE RESEARCH RESULTS}

In the beginning of the research, the students were not able to walk around with freedom and autonomy, and they needed support to go to places for their own basic needs. They were against new places, activities, and experiences, they did not show interest in making choices when offered different activities. They did not have initiatives to scholar or playful activities, without easiness to related to their friends. They also demonstrated difficulties in expressing themselves orally and accept school rules. If teacher would impose the rules or participation in a specific activity, the students offered resistance, even to those activities that were part of their daily routine, as an example, go to the classroom and organize materials used, clean after paints, glues and materials used during the class, and they also demonstrated lack of willingness to meet social habits when interacting with other classmates, specially during meals.

The student A was assiduous, but totally dependent. It was not able to communicate orally, was resistant to scholar activities and social interactions. Denied participating in assignments given, even the simplest ones. After being taught with games and plays, started getting interested in participating on the activities in the classroom and other places with classmates and family. Gradually, started moving by him/herself in those places that were familiar to him/her, demonstrating courage in doing so. Slowly, started a new phase in his/her communication, which started as small sentences until reaching the more elaborated ones. Later, extended his/her vocabulary, using new words in different contexts, also demonstrated happiness when realized success in communication, since his/her requests started being understand and answered, and his/her family members would reward him/her with small gifts after the achievements. Started relationships with classmates, accepting support in his/her movements when needed, answered well to questions that classmates would do. Also started accepting more different food offered by the school, used changing room after physical education classes, was interested in being part of the learning process in the classroom and started participating more with classmates.

The student B was relatively autonomous. He/she would walk around the school, but often would forget where he/she was going and what would do. Did not have good oral expression and had the need to be questioned to elaborate the answers, complete his/her psychological-linguistic development, were not literate and need to be motived to learn. Slowly started questioning the activities and the need to execute them, demonstrating interest in participating and concluding them.

Using games and plays were demonstrated to be an effective support in learning of this student. It was possible to observe improvement in his/her communication, easiness in expressing his/her ideas and 
socialization. It was observed during this process that the anxiety present in the fulfillment of the activities was substituted by the pleasure of discoveries and the possibilities and acceptance inside a social group.

\section{CONCLUSION}

The development of this study enabled an analysis of the importance of the utilization of Games and Plays to facilitate the socialization and oral communication of blind students with Multiple Disabilities.

The experience in the classroom showed beneficial, important, and necessary in the pedagogical field. The students who participated in this research had low self-steam, had difficulties in organizing his/her thoughts, communicate, move, and interact with other classmates. They had the need to learn basic concepts of hygiene and spatial orientation, that lead to challenges in their social and educational inclusion. Using the games and plays, it was possible to perceive the importance of diversification of activities, using simple materials, creating ludic activities, and obtaining harmonic results in their learning.

Therefore, it is evident, through the results obtained, that the games associated with plays, and their ludic, cognitive, social and psychological aspects, have an important role in enable a rich and motivating environment to the students, exceeding the fun role and contributing actively to the students' learning. Using the games and plays contributed noticeably to the development of the students' abilities, resulting in expressive results in favor to their learning, enabling social experiences and communication during playing. Another aspect perceived during this process was the improvement in memorization of some concepts that were not assimilated before. This achievement was done through an individual creation process, leading the students to review and reinforce the learning acquired inside the school. 


\section{REFERENCES}

ANDRÉ, Marli Eliza Dalmazo Afonso de. Etnografia na Prática Escolar. 18ed. Campinas: Papirus. 2012. (Série Pedagógica).

ASSUMPÇÃO, Francisco Baptista, \& VALLE, Luiza Elena Leite Ribeiro do. (Orgs.) Aprendizagem, linguagem e pensamento. Rio de Janeiro: Wak Ed. 2008. (neuropsicologia aplicada; v. 1).

BOATO, Elvio Marcos. Henri Wallom e a Deficiência Múltipla: uma proposta de intervenção pedagógica. São Paulo: Loyola, 2009.

BRONFENBRENNER, Urie. A ecologia do desenvolvimento humano: experimentos naturais e planejados. [Tradução Maria Adriana Veríssimo Veronese]. 2 Reimpressão. Porto Alegre: Artes Médicas, 2002.

CARVALHO, Erenice Natália Soares de. Programa de Capacitação de Recursos Humanos do Ensino Fundamental: Deficiência Múltipla Vol. 1. Fascículos I - II - III. Brasília: Ministério da Educação, Secretaria de Educação Especial, 2000. (Série Atualidades Pedagógicas 5). Disponível em: http://portal.mec.gov.br/seesp/arquivos/pdf/def_multipla_1.pdf. Acesso em: 28 fev. 2017.

GLAT, Rosana, \& PLETSCH, Marcia Denise. Inclusão escolar de alunos com necessidades especiais. Rio de Janeiro: Editora da Universidade do Estado do Rio de Janeiro 2011.

GLAT, Rosana, \& PLETSCH, Marcia Denise (Organizadoras). Estratégias diferenciadas para alunos com necessidades especiais. Rio de Janeiro: EdUERJ, 2013.

JESUS, Elisabeth Ferreira. Deficiência Múltipla e o Modelo Ecológico Funcional. Disponível em: http://www.ibc.gov.br/educacao-basica/prea - Acesso em: 27 fev. 2017.

KIRK, Samuel Alexander \& GALlAGHER, James J. Educação da Criança Excepcional. 3. ed. [Tradução Marília Zanella Sanvicente]. São Paulo: Martins Fontes Editora Ltda. 2002.

MAIA, Maria Vitória Campos Mamede. Criar e brincar: o lúdico no processo de ensino e aprendizagem. Rio de Janeiro: Wak Editora, 2014.

MALHEIROS, Bruno Taranto. Metodologia da pesquisa em educação. Rio de Janeiro: LTC, 2011.

MARTÍN, Manuel Bueno \& BUENO, Salvador Toro. Deficiência Visual: aspectos psicoevolutivos e educativos. [Trad. Magali de Lourdes Pedro]. São Paulo: Santos, 2003.

MEYER, Ivanise Corrêa Rezende. Brincar e viver: projetos em educação infantil. 5ed. Rio de Janeiro: Wak Editora, 2011.

NUNES, Leila Regina d'Oliveira de Paula (Org.). Favorecendo o desenvolvimento da comunicação em crianças e jovens com necessidades educacionais especiais. Rio de Janeiro: Qualitymark Editora Ltda. 2003.

PLETSCH, Márcia Denise. Multiple disabilities: teacher training and teaching-learning processes. Cad. Pesqui., São Paulo, v. 45, n. 155, p. 12-29, mar. 2015. Disponível em: http://www.scielo.br/scielo.php?script=sci_arttext\&pid=S0100-15742015000100012\&lng=pt\&nrm=iso. 
Acesso em: 01 Abr. 2017. http://dx.doi.org/10.1590/198053142862. Acesso em: 01 Abr 2017.

SIAULYS, Mara Olímpia de Campos \& ORMELEZI, Eliana Maria \& BRIANT, Maria Emília (orgs.), A deficiência visual associada à deficiência múltipla e o atendimento educacional especializado. Encarando desafios e construindo possibilidades. São Paulo: Laramara, 2010.

VISCA, Jorge. Introducción a los juegos lógicos en el tratamento psicopedagógico. Buenos Aires: Visca \& Visca, 2009.

WINNICOTT, Donald Woods. O Brincar \& a Realidade, Rio de Janeiro: Imago editora, 1975. (Coleção Psicologia Psicanalítica). 